\title{
قائمة المختصرات
}

Bibliotheca orientalis: Bibliotheca orientalis. Nederlands Inst. Voor het Nabije Oosten (Leyde).

BIE: Bulletin de l'Institut Égyptien, (le Caire)

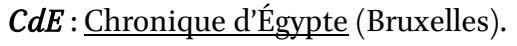

$E E F$ : Egypt Exploration Fund (London).

$G M$ : Göttinger Miszellen. Beiträge zur ägyptologischen Diskussion, (Göttinger).

JEA: Journal of Egyptian Archaeology, (London).

Journal of Laryngology \& Otology: An International medical journal of Laryngology, Otology, Rhinology, and in allied Sciences, (Claverdon).

Medicinhistorisk Ärsbok: Published by Museum of Medical History, (Stockholm).

$P S B A$ : Proceedings of the Society of Biblical Archaeology, (London).

Rev. du GREPAL: Groupe de Recherche pour l'Archéologie au Levant, (Paris). 
(before the surgery) ${ }^{(1)}$." This work proves that the practice of tracheotomy surgery was known as a branch of Medicine in ancient Egypt.

The way in which the knife rather than the lozenge-shape of the lancet, which allows the scalpel to be turned at right angles after its introduction, point to a special operation of respiration obtained by incising the trachea ${ }^{(2)}$.

\section{Conclusion:}

In sum, the studied scene can be interpreted as an instructive procession of surgery, especially in tracheotomy that was being practiced in the so-called pr-anx. The related elements in the studied labels' scenes (Serekh, boats, individuals, symbols on stand, and anx $m s$ signs) maybe define a celebration of opening a new pr-anx in the presence of the king himself who came in his royal boat.

\footnotetext{
(1) E. StRounaL and Others, The Medicine of the Ancient Egyptians. I: Surgery, Gynecology, Obstetrics, and Pediatrics, Cairo-New York, 2014, p. 27.

${ }^{(2)}$ Ibid., p. 92.
} 
2) Logically, the surgeons used knives, hooks, forceps, scales, spoons and saws. Therefore, it is normal to see the surgeon uses a knife into the chest of the patient as it was illustrated in these labels.

3) Evidently, the first recorded physician dates back to Egypt (2667$2648^{\mathrm{BC}}$ ) named Imhotep and the first surgery performed in $275^{\mathrm{BC}}$ together with the famous dentist Hesy-re who lived in the time of Djeser $^{(1)}$. This indicates the existence of specialization in the medical practice of ancient Egypt.

4) The knowledge of ancient Egyptian surgery was actually impressive. Ghalioungui gave several ancient texts' examples of the methods of treating fractures and wounds, circumcision, trepanning, amputating limbs in addition to tracheotomy ${ }^{(2)}$. For examples, there is an indication for surgery in the neck area using a knife (Cf. Ebers Pap. 872 ). Clearly, in this document, neck surgery is described in general the opening of the trachea ${ }^{(3)}$, and including: 'If a person is infected with the accumulation of fatty tumour in the neck ..... this disease will be treated with a knife ${ }^{(4)}$. It is noted that the tumours were treated with a knife, with a scalpel heated in the fire ${ }^{(5)}$.

The second example comes from E. Smith Pap. (1: 1,1-1,12) which recoded the steps of examining the patient before doing the surgery practice as follows: “... when priest of Sekhmet and physician places his hands or fingers [on the head], the leg and the heart, then he measures the heart, because (it beats) in every artery of every limb. Therefore, the physician will know what is coming out of it and what is happening inside

\footnotetext{
${ }^{(1)}$ D.S. Robinson \& D.L. BIRD, Essentials of Dental Assisting, Missouri, 2013, p.3.

${ }^{(2)}$ Cf. P. GhalIounguI, "Surgical Procedures in Ancient Egypt", in: Medicinhistorisk Ärsbok (1967), pp.25-39.

${ }^{(3)}$ H. JоAснім, Papyrus Ebers - das älteste Buch über Heilkunde, Berlin, 189o. S. 188.

(4) SOSATH, op.cit., S.18-19.

${ }^{(5)}$ Ghalioungui, The House of Life. Per Ankh, p. $88 \mathrm{f}$.
} 
c) The injured man puts his arms back in surrender.

These details are similar to the scenes of the studied labels; therefore, the practice, especially in the concentration on the wound, whether in looking or treatment here, was not a killing or sacrifice but a surgery.

Now, let us ask a new question: what kind of surgery is that practice? The answer can be found in the direction of the sharp tool, which appears in the hand of the surgeon. The tool heading towards the chest of the patient; so it was a surgery of tracheotomy.

It might be alleged that such depictions are difficult to reconcile with tracheotomy from an anatomical point of view. Furthermore, there are some opinions considerate that Egyptian surgery included only minor procedures, even at its zenith during the Late Period. Therefore, it is hard to believe that they would have developed such an advanced procedure at such an early time ${ }^{(1)}$.

The previous view depends only on the speculation, because the ancient Egyptian civilization achieved great development that stunned the modern world. One of the best-known branches was the medicine, which was highly advanced for its time, including setting of bones, dentistry, an extensive set of pharmacopoeia and surgery field since the beginning of civilization at least in the late fourth millennium ${ }^{\mathrm{BC}}$ until the end of the Late Period influenced later traditions, including the Greeks ${ }^{(2)}$. Let us know the following evidences:

1) The Egyptians knew the details of the human body in the pictorial signs of their ancient writing, dated back to the early ages, which attest to them with the experience in anatomy since ancient times.

\footnotetext{
${ }^{(1)}$ P. BLOMSTEDT, "Tracheostomy in ancient Egypt", The Journal of Laryngology \& Otology 128 (2014), pp. 665-668.

${ }^{(2)}$ https://en.wikipedia.org/wiki/Ancient_Egyptian_medicine.
} 
Accordingly, the studied scene can be interpreted as instructive practice of surgery; the first sitting man, who has a sharp tool, was a physician and the standing person was a great physician who gives him the medical instructions in order to heal the other sitting man, the patient, during the surgery procession ${ }^{(1)}$.

Likewise, we have an excellent Roman frieze, depicting battlefieldsurgery (Fig. 27), is the key to understand Roman surgery practices and techniques ${ }^{(2)}$.

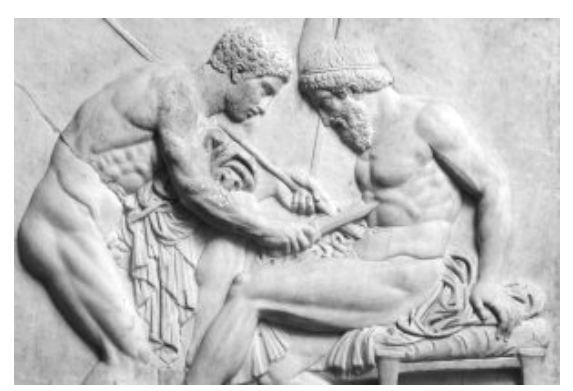

Fig. 27

Roman surgery practice

As we see through the previous scene, a physician tries to treat a wounded soldier. The surgeon extracts a spearhead from the body of the wounded man who was infected in the field battle. The following points must be observed:

a) surgeon uses a dagger in that surgery.

b) The surgeon sat down, face to face, in the front of the wounded man.

\footnotetext{
(1) There is a suggestion proposed that the arms of patient may have been tied simply to prevent the sick man from struggling or moving because of the pain feeling, as even a willing patient would instinctively try to do. This action can be explained very simply as a well-known precaution of surgeons, to avoid disorderly reflexes that would hinder the action of the surgeon-priest. See Menu, op.cit., p.166 (b).

${ }^{(2)}$ http://luccav.com/2014/o2/o8/field-doctors-in-ancient-warfare.
} 
25). This standing man, who bases on a long stick, is 'superintendent', because he appears traditionally in the scenes of crafts to give his instructions to his followers. For example, there is a scene of gold processing in the tomb of Khay, 'gold-washer of the treasury of Pharaoh', at Saqqara (Fig.26) $)^{(1)}$. It depicts a standing superintendent bases on a stick to oversee the workers during the work.

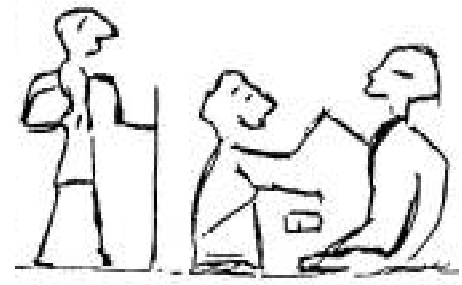

Fig.25

Standing man behind the two sitting men

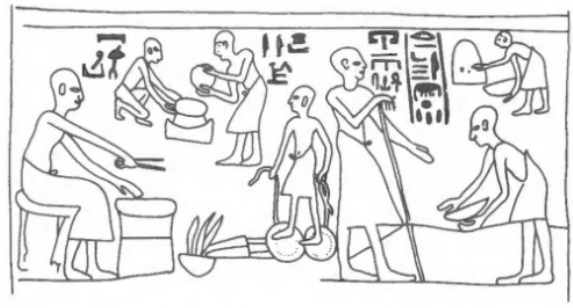

Fig. 26

Scene of a superintendent in the Ramesside tomb of Khay

4) The second sitting man just put his arms behind him without tying them. This indicates that he was satisfied concerning this practice.

\footnotetext{
(1) The EES-Leiden mission at Saqqâra excavated this tomb in 1986. It was built for Khay, 'goldwasher of the Lord of the Two Lands,' and his wife, 'the chantress of Amun' Tawerethetepti. Most of the scenes are extant. See G.T. Martin, "The Saqqâra New Kingdom Necropolis Excavations, 1986: Preliminary Report," JEA 73 (1987), pp.1-3.
} 
standing man who is holding a stick and watching the other two men. Now, we need to analyze the contents of that scene as follows:

1) Above the heads of those sitting men, there is a shape (Fig. 24). If we try to divide this shape into parts우, we will discover that every part has the shape of the sign $f$ anx. This means that the shape is a series of anx sign of representing life. Therefore, the scene has a relation to the life, not to the death or killing. It must be interpreted in this context as the life that is given from one person to the other ${ }^{(1)}$. Evidently, Ancient Egypt knew the so-called pr-anx "House of life" as a teaching school of medicine, where all physicians received their training and attached to temples and located in several towns (2).

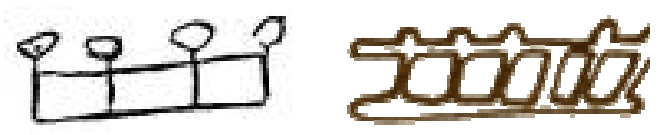

Fig. 24

Series of "ankh" hieroglyphs sign

2) The box, which appears before the man who has the sharp tool, it may be dedicated to keeping the other similar tools.

3) The standing man pointed his arm to guide the man, who has a sharp tool, how to do the procession accurately to the other man (Fig.

${ }^{(1)}$ Cf. L. PAHOR, "Ear, Nose and Throat in Ancient Egypt," Journal of Laryngology \& Otology 106 (1992), p. 773-779.

${ }^{(2)}$ P. GhaliounguI, The House of Life. Per Ankh. Magic and Medical Science in Ancient Egypt, Amsterdam, 1973, p. 28. Some scholars think that pr-anx was rather functioned like 'centre of documentation', or 'scriptoria', where books were collected or copied. See A. GARDINER, "The house of life," JEA 24 (1938), p. 157; G. LEFEBVRE, Essai sur la médecine égyptienne de l'époque pharaonique, Paris, 1956, p. 18. On the other hand, some scholars saw that the library called prmDAt, but pr-anx was considered as academies, where scholars, physicians and sometimes philosophers used to meet. See L. Habachi \& P. Ghalioungui, The "House of Life" of Bubastis, $C d E$ 56, No. 91 (1971), pp.59-71; P. GHALIOUNGUI, op.cit., p.66; F. vON KAENEL, Les prêtres-ouâb de Sekhmet et les conjurateurs de Serket, Paris, 1984, p. 305; P. PRIORESCHI, A History of Medicine, I: Primitive and ancient medicine, ОМАнА, 1999, p.284. 
the hawk ${ }^{(1)}$. Therefore, this symbol represents a territory of the ancient region of Egypt.

Now, let us ask about the following points:

$\checkmark$ What were this ceremony and this building?

$\checkmark$ What was the relation among the serekh, boat, symbol on stand and $m s$ sign?

The answer for the previous questions gives a better idea of the mysterious event (Fig. 23). The ceremony is relating achievement a new projection of erecting a building or institution. This ceremony was in the presence of the king himself, who reached to attend this festival by his royal boat together with his queens.

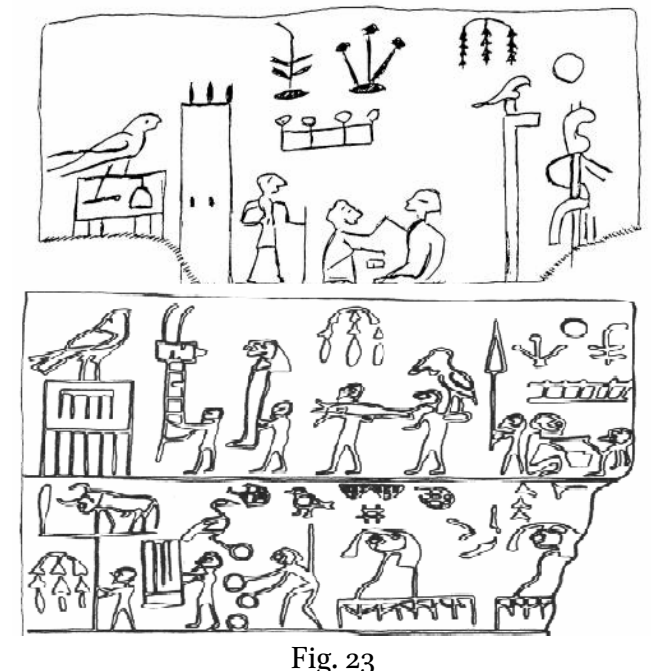

Reconstruction of the two studied scenes together

The question now is what was the purpose of that institution? The answer is included in the studied scene that illustrates a seated man plunging a sharp tool into another seated man's chest in addition to a

\footnotetext{
${ }^{(1)}$ MENU, op.cit., p.166.
} 
a ceremony of opening a new fortress to protect Egypt against the "arch-using setjet-folks", probably of Libyan. (Fig. 22) $)^{(1)}$.

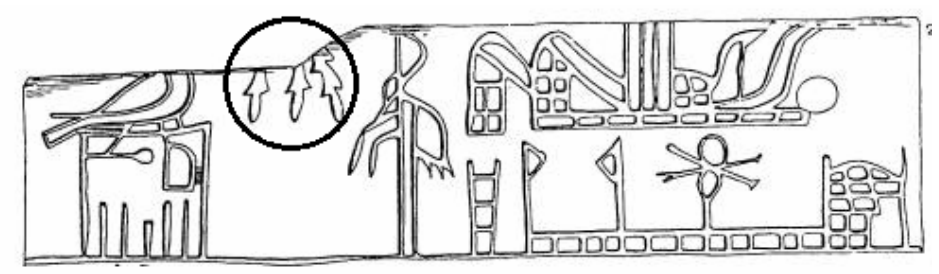

Fig. 21

The upper part of the label of Philadelphia University Museum E9396

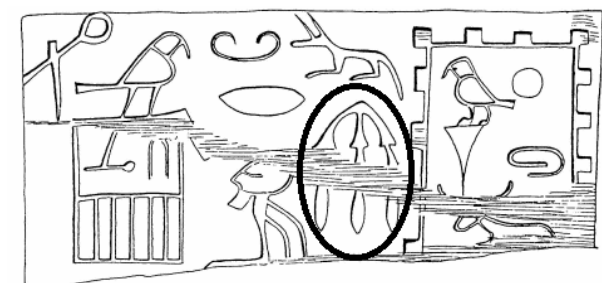

Fig. 22

The ivory label (Aha 5 , Kahl 282, Abydos B18)

Accordingly, the existence of $m s$ sign in the studied labels' scenes indicates to the opening of a new official project.

2) The depiction of the Cairo Museum label (JE 34907), represents the fence surrounding a house or office, which suggests that the events took place within a specific compound.

3) On the Cairo Museum label (JE 34907-8); there is a symbol on stand窟. This symbol may be a wader or a stork that was represented repeatedly in the documents of the dynasty 5 . The bird, like the heron, may refer to a confederate authority under the supreme command of

(1) PETRIE, Royal Tombs, p. 21, pls. 3.2, 11.1; LEGGE, op.cit., p. 248 (n.6); S. Schott, op.cit., pl. 7, fig. 13; VANDIER, op.cit., p. 834; Weill, op.cit., p. 31; HELCK, op.cit., S.145; SERRANO, op.cit., p. 87; J. KAHL, 'Die frühen Schriftzeugnisse aus dem Grab U-j in Umm el-Qaab,' $C d E 78$ (2003), S.132, fig. 12. 
The scene moulded on this plaque depicts Nergal in the act of executing the Igitelu "monoculus". On the right stands a monster, hands tied behind its back. On the left the warrior god Nergal, bow slung over the shoulder, with his left hand holds the captive down by one of the projections from his head, and with his right hand a blade into its stomach ${ }^{(1)}$.

Here we can note the hands' movement of the two figures, whether the killer or the killed figure, while they are standing up, so the purpose is killing, but the hands' position of the two sitting men in our labels scenes is different from the previous practice.

17) The assumption of human sacrifice, in the tombs of the first kings of Egypt at Abydos, is just because the existence of this funeral custom in the royal tombs of Ur in Mesopotamia ${ }^{(2)}$.

\section{New suggestion of the studied scene elements:}

The events and purpose of such labels' scenes are not clear. Accordingly, the theory of rebirth ceremony or human sacrifice in ancient Egypt during the $1^{\text {st }}$ Dynasty, has no strong evidence ${ }^{(3)}$. In addition to the earlier theories, there is another suggestion about what is happening in the studied scene, according to my belief, which could have been interpreted through studying the related elements in the labels scenes as follows:

1) The sign $m s$ appears in many labels and in every case it can be translated as the proto-hieroglyphic word What is more, this sign appears too in scenes of erecting building like a temple of the goddess Neith (Fig. 21). Moreover, the ms sign appears in

${ }^{(1)}$ A.R. GeORGE, "Nergal and the Babylonian Cyclops", Bibliotheca Orientalis 6 (2012), p. 421.

${ }^{(2)}$ cf. L. WATRIN, "Les sacrifices humains à Abydos lors des funérailles des rois de la 1ère dynastie: un mirage thinite", Rev. du GREPAL 2 (2004), pp. 6-17.

(3) PAHOR, loc.cit.

(4) Wb. II, $143(1)$. 
human sacrifice, which demonstrates the position of the victim, is the scene of Polyxena ${ }^{(1)}$. It recorded the suitable position of Polyxena, who was tied, for obtaining the larger amount of her blood through killing her in the neck with a dagger (Fig. 19) ${ }^{(2)}$. These details did not exist here in the depictions of our labels scenes.

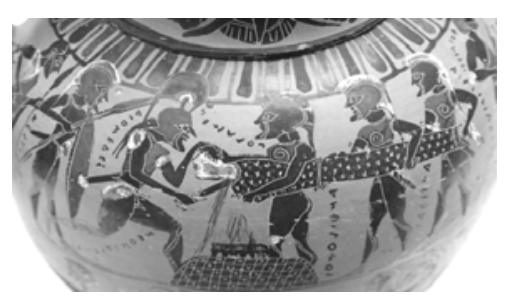

Fig. 19

The sacrifice of Polyxena by the triumphant Greeks, Trojan War, c. 570-550 BC

16) The most prominent example of killing method by the dagger is a clay plaque found in Khafaje (Iraq) and dated to the early secondmillennium from the Larsa-period (Fig. 20) $)^{(3)}$.

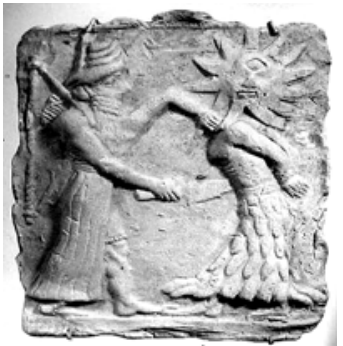

Fig. 20

A clay plaque of Khafaje

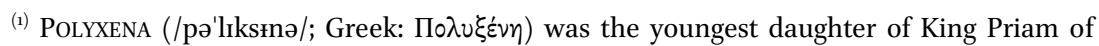
Troy and his queen, Hecuba. See G.E. Duckworth, "Polyxena", Collier's Encyclopedia 19 (1976), p. 231.

${ }^{(2)}$ Cf. D. Hughes, Human Sacrifice in ancient Greece, London - New York, 2003, p.11.

(3) This plaque was found in Sin temple in Khafaje, east of Baghdad, Iraq. It is now in the Oriental Institute Museum in Chicago (no. 1961.488). It is depicting the moon god Sin slaying a monocular monster, but a recent article on the subject argues that it is actually Nergal instead. See A.R. George, "Nergal and the Babylonian Cyclops", Bibliotheca orientalis 6 (2012), p. 421. 
13) Evidently, the pyramids and the mastabas of lesser royals were constructed in the same time ${ }^{(1)}$. Likewise, people of Early Period also desired to build their own tombs around the tomb of their kings according their offices. From the time of Djet onwards, the owners of the subsidiary tombs often be identified. Exceptionally their names were recorded in red ink on the walls of graves, but mostly they were inscribed on a small stela in the tomb. This identification sometimes included a title. The most elaborate stela, also found in a grave next to Qa'a's burial chamber, belonged to a man named Sabef.

On this stela, Sabef is represented standing and holding a long stick, the usual posture of a high official. From his titulary, we see that he was 'Keeper of the Tomb' of Qa'a. He was also a 'priest', 'Keeper of the Secrets and Decrees', and a 'confident of the king'. This could be interpreted as Sabef had a votive stela placed in the tomb of his king; hoping he would thus be able to take part in the king's afterlife not more $^{(2)}$.

14) The ancient Egyptians, during the $1^{\text {st }}$ Dynasty, knew certainly the funerary sacrifice of animals in Umm el-Qaab, not the funerary human sacrifice. Evidence for this burial was recovered in the scattered debris of earlier excavations in Cemetery (B). The remains of two geese bones were found near the triple row of subsidiary chambers belonging to Aha's funerary complex (BI6 - near W4a $)^{(3)}$.

15) The human sacrifices had certain ceremonies, including that the victim is restricted to prevent resistance, as well as the blood of this victim is obtained by cutting through the neck until the priest gets a larger amount of blood as offerings to the gods. The best example of

\footnotetext{
${ }^{(1)}$ G.A. REISNER, Mycerinus. The Temples of the Third Pyramid at Giza, Cambridge, 1931, p. 3.

${ }^{(2)}$ www.ancient-egypt.org.

(3) D.V. FloRes, The Funerary Sacrifice of Animals during the Predynastic Period, Ph.D. of Philosophy, Department of Near and Middle Eastern Civilizations - University of Toronto, Not published, 1999, p.161 f.
} 
"All of Upper Egypt was dying of hunger and everyone was eating his children, but (I) did not allow (anyone) to die of hunger in this nome ${ }^{\text {(1) }}$.

Furthermore, the cutting parts of the body or the dead ones in the age of youth were buried in the subsidiary pits as honoring them, because they died during their native tasks such as wars or working for the king. Therefore, they deserved to be buried around their king.

11) If the ancient Egyptians wanted to present human sacrifices or their blood to the kings or to gods, they must cut their heads, so there are traces of the incision on the vertebrae in order to get a large amount of blood ${ }^{(2)}$. Actually, it had happened when four skulls were found in Nekhen during the 2003 Season. By lining up the cut marks, we can see the head was rotated slightly to the left ${ }^{(3)}$.

On our labels, we do not see the kneeling man plunges a sharp weapon to the neck, but into the chest of the seated man. Accordingly, the aim was not a sacrifice, but it needs more discussion in the light of the documents.

12) With regard to Djer tomb at Abydos, we must know that this tomb, which had 318 burial pits surrounding the king's tomb as well as a number of other burial pits at his funerary enclosure (about two kilometres away), may have been a mortuary temple. It was believed by the Egyptians of the late Middle Kingdom as the tomb of Osiris himself, and this belief lasted even into the Roman period ${ }^{(4)}$. Therefore, the ancient Egyptians had chosen that tomb and its surroundings a sacred building to bury their deceased ones.

\footnotetext{
(1) J. VANDIER, Mo'alla: La Tombe d'Ankhtifi et La Tombe de Sébekhotep, BdE 18 (1950), pp.1434, 220-1; S.J. Seidlmayer, "The First Intermediate Period," in: I. Shaw (ed.), The Oxford History of Ancient Egypt, Oxford, 2000, p.129; A. B. Lloyd, Ancient Egypt: State and Society, Oxford, 2014,

${ }^{(2)}$ CRUBÉZY \& MidANT-REYNES, op.cit., p.95.

(3) P. Dougherty, "A Little More Off the Top", Nekhen News 16 (2004), p.11.

${ }^{(4)}$ www.touregypt.net.
} p.177. 
was done before the door of the royal palace ${ }^{(1)}$. That ritual must be before the royal tomb not before the royal palace.

9) How we can agree with the opinion of human sacrifice that depends on the mere existence of a bowl of blood! In reality, we do not know what was inside it, but if we accept that it contained blood, despite the pictures, there is not enough information as to why it was done, what happened with the blood in the bowl, or for whom it was done ${ }^{(2)}$.

10) The ritual cannibalism was not a traditional practice, because there is no direct evidence that cannibalism normally practiced in ancient Egypt. There is a suggestion that has occurred during times of great famine and drought. Ankhtifi (Ankhtify), Nomarch of the $3^{\text {rd }}$ Nome of Upper Egypt during the First Intermediate Period, left on his tomb this text:

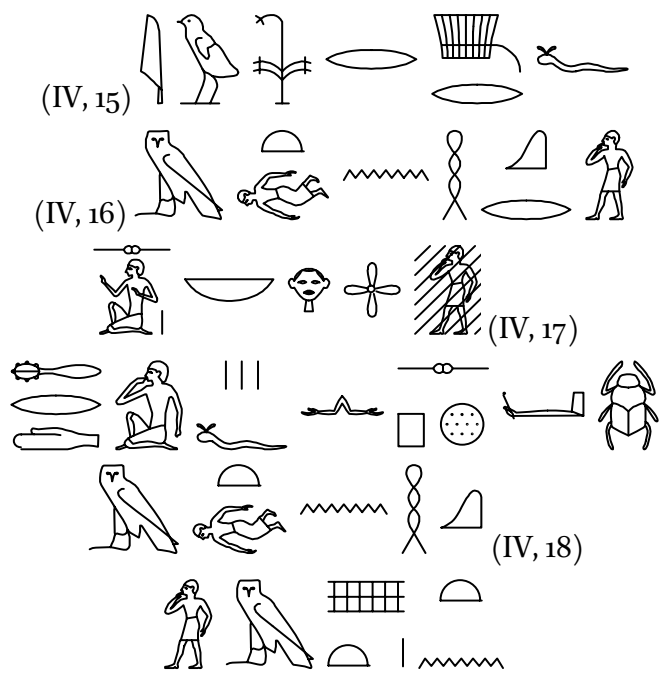

“(IV, 15) ... iw Sma r-Dr.f (IV, 16) mwt n Hqr s nb Hr wnm (IV, 17) Xrdw.f n sp iTt(.i) xpr (wa nb) mwt n Hqr (IV, 18) m spAt tn

\footnotetext{
${ }^{(1)} \mathrm{MENU}$, loc.cit.

${ }^{(2)}$ PAHOR, op.cit.
} 
2) The theory of embalming is not accepted, because the person is not lying on the bed, but he sets on the ground. Apparently, he is still alive.

3) The fetish is not known that it related to the practice of human sacrifice, or not, because there is a separation line between it and those men.

4) There is no evidence can be identified on the kinds of those victims of these types of sacrifice rituals if they really included servants, enemies, prisoners, convicts and virgins or not ${ }^{(1)}$.

5) Surely, there is no evidence to suggest that victims were ever buried alive. It was supposed to be buried the victims in a complete form of body, without the slaughter or a stab wound; so that they could serve the King after their rebirth. G. Reisener suggested that the tombs of King Djer and King Aha were filled with the royal wife and the servants who were sacrificed by being buried alive with their tools ${ }^{(2)}$.

6) The Narmer Palette contains some of the earliest features for important events, including an execration procession $^{(3)}$, not execration rituals or sacrifices; because the killed bodies have not put before a divine emblem. They were killed on land of battle not in a temple.

7) Although criminals and enemies of country have been killed in a ritualized manner at the temple gates, this practice cannot be considered as a real human sacrifice ${ }^{(4)}$. It is noted that the two arms of the person, to whom the tool is headed, are not tied up with a rope. This indicates that he is not a prisoner of war or imprisoned.

8) On the label of Cairo Museum $J E$ 34907, there is a building. B. Menu thinks that this building demonstrates that the ritual murder

\footnotetext{
${ }^{(1)}$ www.mummies2pyramids.info.

${ }^{(2)}$ www.toptenz.net.

(3) Ibid.

${ }^{(4)}$ www.ancient-egypt.org.
} 
In general, these studied labels commemorating the same event that shows a man kneeling down with his arms tied behind his back, and in front of him, another man plunges a long knife into his chest. There is no written text to shed further light on this scene, but there can be little doubt that it involved the ritual killing of a human prisoner as part of a ceremony of kingship ${ }^{(1)}$.

Lastly, the practice of this type of human sacrifice ceased abruptly at the end of the $1^{\text {st }}$ dynasty in the reign of Qa'a, because the absence of the subsidiary graves in connection with the $2{ }^{\text {nd }}$ Dynasty enclosure and tombs ${ }^{(2)}$. Apparently, it perhaps had survived in a symbolic way; when statues were placed in tombs to take the place of actual working people during the Old Kingdom ${ }^{(3)}$.

\section{Re-examination for the previous theories:}

The topic of the studied labels scene is explored as 'Human sacrifice' and its related ideas ${ }^{(4)}$, but we can re-examine them in order to recognize the shortcomings, deficiencies and the irrational points, especially with the existence of several problems in analyzing concerning this mysterious scene. Chief among them are the following points:

1) Whether this was a celebration to provide the $h k_{3} w$, or the king's body being embalmed in preparation for a funeral ritual is still uncertain, as the meaning of these proto-hieroglyphs are very tentative ${ }^{(5)}$

\footnotetext{
(1) WiLkINSON, The Rise and Fall of Ancient Egypt, p.65.

${ }^{(2)}$ L. BESTOCK, The Development of Royal Funerary Cult at Abydos: Two Funerary Enclosures from the reign of Aha, Wiesbaden, 2009, p.89.

${ }^{(3)}$ B. BRIER, The Encyclopedia of Mummies, New York, 1998, p. 186.

(4) CRubÉzy \& MidANT-ReYNes, loc.cit.

(5) Cf. J. KAHL, "Hieroglyphic Writing during the Fourth Millennium ${ }^{\mathrm{BC}}$ : an Analysis of Systems," Archéo-Nil 11, 2001, pp.102-134.
} 
same time as the royal burial. This can mean either that all the subsidiary burials predated the royal burial ${ }^{(1)}$.

It is somewhat surprising that some of them held high offices during their lives. The best example of those high officials, who buried in the tombs next to their king and had a very distinct relationship to the king, was Sabef who is known from a stela (Cairo $C G$ 14631) found in one of the chambers of Qa'a's tomb at Umm el-Qa'ab ${ }^{(2)}$. This would imply that Sabef was buried at the latest at the same time as Qa'a. This is seen as evidence of retainer sacrifice at the end of the $1^{\text {st }}$ Dynasty ${ }^{(3)}$.

The most clear example is the feature of Djer burial where the presence of 318 subsidiary burials around his tomb. Although this short-lived practice of the king, the 318 burials, accompanying him, were the most of any king of the $1^{\text {st }}$ Dynasty. It suggested that the occupants of these tombs were killed at the time of the king's death and represents one example of human sacrifice ${ }^{(4)}$.

In the case of King Aha, the bones scattered around the burial pits were all of young men and women aged 20-25 years old. This indicates that they probably did not die from natural causes, but they were selected for burial with Aha ${ }^{(5)}$.

Around the tomb of Queen Merytnit, most of the skeletons were found facing the same direction, without signs of violence. This suggests that they were not buried alive, since the bodies were all placed in a specific direction for religious purpose, and that they had died previously to be buried. They were killed by poison to be buried with the queen ${ }^{(6)}$.

\footnotetext{
${ }^{(1)}$ www.ancient-egypt.

${ }^{(2)}$ W.B. EMERY, with the Collaboration of A. Klasens, Great Tombs of the First Dynasty, III, London, 1958, pl.39; Weill, op.cit., p.22.

${ }^{(3)}$ WILKINSON, Early Dynastic Egypt, p. 371.

${ }^{(4)}$ http://rateyourmusic.com/list/koeeoaddi_there/early_dynastic_egypt.

${ }^{(5)}$ www.ancient-egypt.org.

${ }^{(6)}$ www.touregypt.net/featurestories/humansac.htm.
} 
6) In the Naqada II Period, one of the discovered bodies showed marks of the throat had been cut before decapitation took place $(?)^{(1)}$.

7) The skull, hands and trunk of the deceased ones, around royal tombs, were often intentionally removed or partly cut to pieces before burial. The whole body was sometimes dismembered completely before burial and artificially arranged. According to the tomb n. 5 at Naqada, not only were the ends broken off; but also in some bones, the cellular structure had been scooped out forcibly, what remains of it is being very firm and strong; and besides this, there were grooves left by gnawing on the bones. After these instances, we could conclude that bodies were sometimes - with all respect - cut up and partly eaten ${ }^{(2)}$.

Moreover, the Pyramid Texts of Unas and Teti (Utterances $273-$ 274) talk of cannibalism to gain power from gods to the king through human sacrifice. This Cannibal Hymn describes the pharaoh as a god who cannibalizes gods: 'A god who lives on his fathers and feeds on his mothers ... who lives on the being of every god, who eats their entrails ... Pharaoh is he who eats men and lives on gods ${ }^{\prime(3)}$. It is a bloodthirsty text, talking about death, killing and devouring of body parts.

8) At the royal cemetery of Umm el-Qa'ab, the tombs of the $1^{\text {st }}$ Dynasty kings from Aha to Qa'a are accompanied by subsidiary burials. These burials arranged in rows or blocks either extending from the royal tomb or surrounding it. The position of the subsidiary tombs, compared to the royal tomb, reflects the relationship of their occupants to the king during life ${ }^{(4)}$.

It is obvious that the superstructure covers the tombs of Semerkhet, Qa'a and the subsidiary burials. Therefore, the burials occurred at the

\footnotetext{
${ }^{(1)}$ www.thekeep.org; www.ancient-egypt.org; www.mummies2pyramids.info.

(2) W.M.F PETRIE, Naqada and Ballas, London, 1896, pp.31-32.

${ }^{(3)}$ www.thekeep.org.

(4) Cf. W. KAISER, "Zu de Konigsgraben der I. Dynastie in Umm el-Qaab," MDAIK 37 (1981), S.247-54.
} 
placed between their legs in two rows, as an act of thanksgiving to gods in exchange for their assistance in the victory against those of Lower Egypt (Fig. 17) ${ }^{(1)}$.

What is more, in a depiction of Seventh Hour from 'The Book of the Amduat' (Imy-dwAt), there is a scene showing the enemies of Osiris being punished via decapitation by Tuthmose III (in whose tomb this painting is). To the left of this scene, the seated god Osiris (protected by a Mehen serpent) acts as the judge of the dead and oversees the execution of those who are his enemies as offerings to him (Fig. 18).

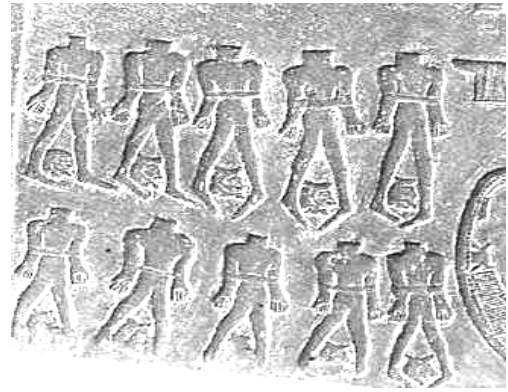

Fig. 17

Ten headless corpses, Narmer

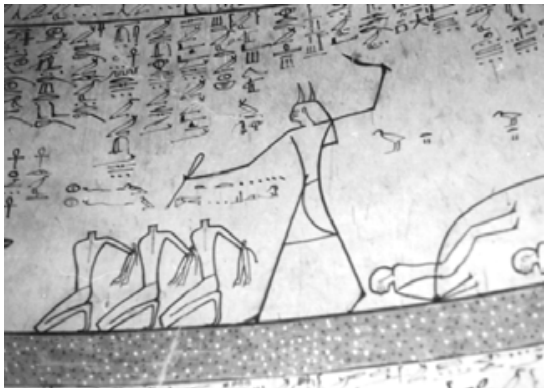

Fig. 18

The death of those prisoners seems to be a tribute to gods on special occasions or feats that have been recorded on such labels ${ }^{(2)}$. Such these actions were not the general rule in the treatment of the ancient Egyptian army against the foreign prisoners during wars.

5) It was believed that the Humans were sacrificed to fertility gods as offerings to ensure a good harvest ${ }^{(3)}$.

(1) E.C. KÖHLER, "History or Ideology? New Reflections on the Narmer Palette and the Nature of Foreign Relations in Predynastic Egypt", in: E.T. Levy and E.C.M. van DEN BRINK (eds.), Egypt and the Levant, London and New York, 2002, p.513; J.R. TAтLOCK, How in Ancient Times They Sacrificed People, A dissertation for the degree of Doctor of Philosophy, The University of Michigan, 2006, p.120.

${ }^{(2)}$ T.A.H. WiLKINSON, The Rise and Fall of Ancient Egypt, New York, 2010, p.65.

${ }^{(3)}$ www.mummies2pyramids.info. 
carry out their work for their master in the afterlife ${ }^{(1)}$. This theory depends on some evidences as follows:

1) One figure appears to put his arms tethered behind his back. The other seems to be plunging a knife into the enemy's chest, while the standing one is an 'executioner-priest' holds a vessel to catch his victim's blood ${ }^{(2)}$.

2) Petrie suggested that the upper half of the label of Aha is apparently duplicated in lower half of another label now carbonized. In front of the name of Aha is a building with the Khaker ornament. Next is $r s \mathrm{mH}$ Ssp, perhaps "receiving (captives of or from) the south and north $^{\prime(3)}$. Once, the use hieroglyph itself suggests that the space in which the activity took place was holy, and thus the activity was a ritual $^{(4)}$.

3) The depiction of Cairo Museum label (JE 34907) represents the fence surrounding a shrine. This suggests that the ritual of killing took place within the shrine compound ${ }^{(5)}$. On the other hand, all of the labels bear a serekh ${ }^{(6)}$. What is more, according to Morris, the Abydos labels include a palace and Horus standard, while the Saqqara label includes images of royal women. This indicates that the act of retainer sacrifice occurred in a clearly royal funeral context ${ }^{(7)}$.

4) One form of human sacrifices had been in the form of slaying criminals and prisoners of war $^{(8)}$. Narmer Palette (Cairo Museum, $J E$ 32169) depicts ten headless corpses of bonded persons with their heads

\footnotetext{
${ }^{(1)}$ PETRIE, op.cit., p. 20; MORRIS, op.cit., p.20.

${ }^{(2)}$ www.mummies2pyramids.info.

(3) PETRIE, op.cit., p. 20; EMERY, op.cit., p. 36; MORRIS, op.cit., p.20; MENU, op.cit., p. 170.

(4) CAMPBELL, loc.cit.

${ }^{(5)}$ www.thekeep.org

${ }^{(6)}$ MenU, loc.cit.

(7) PETRIE, loc.cit.; MORRIS, loc.cit.; CAMPBELL, loc.cit.

${ }^{(8)}$ PAHOR, loc.cit.
} 


\section{3- Theory of human sacrifice:}

Many scholars believe that the labels depictions of Cairo Museum (JE 34907-8) and (JE 70114) might record human sacrifice; because they show a seated man plunging a knife into another seated man's chest as a victim, while he is holding a bowl to catch the blood (Fig.16) ${ }^{(1)}$.

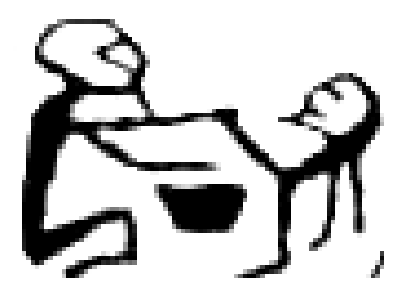

Fig. 16

A seated man plunging a knife into another seated man's chest

(Cairo Museum label, JE 34908)

Accordingly, when this practice happens normally before either gods or men of power, it seems a ritual killing ${ }^{(2)}$. The sacrificed retainers, servants, slaves, even nobles or family members had their own burial pits as part of the Abydos tomb complex of each ruler of the $1^{\text {st }}$ Dynasty. Those people were killed so that they could continue to

\footnotetext{
(1) EMERY, op.cit., p.36; W.B. EMERY, Archaic Egypt: Culture and Civilization of Egypt Five Thousand Years Ago, Baltimore, 1961, pp. 59,75; M. Rice, Egypt's Making. The Origins of Ancient Egypt $5000-2000^{B C}$, London - New York, 1990, p. 121; B. Menu, "Mise à mort cérémonielle et prélèvements royaux sous la 1 ère dynastie (Nârmer-Den)”, Archéo-Nil 11, 2001, p.175; E.F. Morris, "Sacrifice for State: First Dynasty Royal Funerals and the Rites at Macramallah's Rectangle." In: N. Laneri (ed.), Performing Death: Social Analyses of funerary Traditions in the Ancient Near East and Mediterranean, Chicago, 2007, p.20; OHsHIRO, op.cit., pp.57-64; R. Campbell, "Human Sacrifice at Abydos in First Dynasty Egypt," in: www.academia.edu/5261876 (Access in 2/1/2016).

${ }^{(2)}$ Petrie, op.cit., p. 20; E. Crubézy \& B. Midant-Reynes "Les Sacrifices humains à l'époque prédynastique: L'apport de la nécropole d'Adaima," Archéo-Nil 10, 2000, p. 29; Morris, op.cit., p.20; L. Pahor, "Medicine and Surgery in Ancient Egypt" in:

www.touregypt.net/featurestories/humansac.htm (Access in November 14, 2015).
} 
denoting some kinds of spiritual purpose ${ }^{(1)}$.

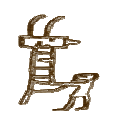

Fig. 15

A ladder of ba

Interpretation of the studied label scene:

Primary, there are two main theories trying to present an interpretation concerning the studied labels scenes as follows:

\section{1- Theory of rebirth celebration:}

D. Cintron tried to interpret these labels scene as a typical postmortem religious $h k 3 w$ 'magic' that celebrates and reinforces the deceased king's transformation from body to be a god and celebrates his victory in rebirth by positioning his place as rightfully beside the place of his ancestors in the abode of the gods ${ }^{(2)}$. Accordingly, that theme is the use of the power of symbolism as $h k_{3} w$ and that this success depends upon specific ceremony and the sanction of his divinity by those ancestors ${ }^{(3)}$.

\section{2- Theory of embalming:}

There is another theory trying to decoding this ambiguous scene. Ohshiro thinks that it actually indicates the mummification process, with the right-hand person being mummified and the left-hand an embalmer. Obviously, there is ms sign that means "give birth", so Aha is shown as being re-born after the embalming process of his body ${ }^{(4)}$.

\footnotetext{
${ }^{(1)}$ Cintron, loc.cit.

${ }^{(2)}$ Ibid., pp. 2-3.

${ }^{(3)}$ CInTRON, loc.cit.

(4) OHSHIRO, op.cit., pp.6o-62.
} 
Otherwise, the sign $\int\left(\mathrm{A}_{53}\right)$ in the form of a mummy may denote the newly dead Djer ${ }^{(1)}$, or it belongs to the mummy of Aha ${ }^{(2)}$.

3) A pelican (Fig. 13) denotes the bA of Djer ${ }^{(3)}$, or the $p s d t$-pelican representing the original gods of ancient Egypt, the Ennead ${ }^{(4)}$.

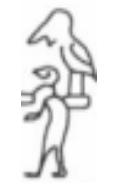

Fig. 13

A pelican figure

4) The Narmer catfish was symbol of the original $b a$ of the kingship (Fig. 14) ${ }^{(5)}$, or representing the first king, Nar(-mr), who followed gods ${ }^{(6)}$.

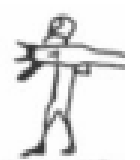

Fig. 14

Narmer catfish symbol

5) A ladder on which, the $b a$ of the newly deceased Djer may ascend to the sky to join his forebears (Fig. 15). It seems to possess either two poles for leaning toward its target, or two of the odd antennae-like fixtures seen on figures as part of predynastic rock art,

\footnotetext{
(1) Ibid.

${ }^{(2)}$ R.O. Faulkner, The Ancient Egyptian Pyramid Texts, Oxford, 1969, p.13.

${ }^{(3)}$ Cintron, loc.cit.

(4) PT 278 associates the $p s d t$ pelican with the Ennead, of which both the greater and lesser are named both in the Turin Canon and by Manetho as part of a list of kings preceding the first dynasty. Cf. FAULKNER, op.cit., p.13

${ }^{(5)}$ Cintron, loc.cit.

${ }^{(6)}$ FAULKNER, loc.cit.
} 


\section{0,}

Fig. 9

The likely sign Ssp

Accordingly, there is a translation gathered the two previous elements and suggested as "receive the South and North" ${ }^{\text {(1) }}$.

Additionally, another translation of Ssp as 'have, hold, grab' concerning the deceased and his body parts ${ }^{(2)}$. This word combined with the symbol $\Delta$ (M44), mounted on the pole (Fig. 10), spd for 'effective', translated as 'Djer is attaining effective' means his kA becomes $A x^{(3)}$.

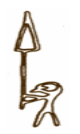

Fig. 10

The symbol $\triangle\left(M_{44}\right)$ mounted on the pole

On the other hand, the Aha label shows what may even be sign (A53) for hnty or $t w t^{(4)}$ (Fig. 11) together with the $m s$ sign (Fig. 12). This combination of signs means a statue is being carved. In this case spd could be translated as skilled ${ }^{(5)}$.

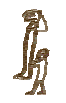

Fig. 11

The twt sign

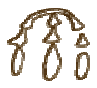

Fig. 12

The ms sign

\footnotetext{
${ }^{(1)}$ Wb. IV, 530-533; Baud \& Étienne, op.cit., p.99.

(2) Ibid.

(3) Cintron, op.cit., pp. 2-3

(4) GARDINER, op.cit., p.444.

${ }^{(5)}$ FAULKNER, op.cit., p.223; CinTRON, loc.cit.
} 
studied labels scenes (Fig. 7) as follows:

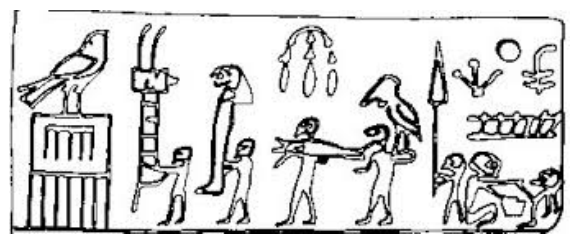

Fig. 7

$1^{\text {st }}$ row of the studied label (Cairo Museum label, $J E$ 70114)

1) The symbols of the scene above seem to denote an early form of the $n s w$-bit name with a clump of papyrus 19 )

(L2), to give a name possibly denoted as $n s w-m H w$, (Fig. 8$)^{(1)}$. There is another reading as rs - $\mathrm{mHw}$ "Upper and Lower Egypt" ${ }^{\text {"(2) }}$.

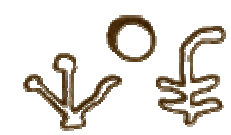

Fig. 8

An early form of the $n s w$-bit or rs - mHw

2) Below the previous name is either what is more likely sign Pop-p. (O43), šsp (Fig. 9), which may mean as 'statue ${ }^{(3)}$, 'receive', as part of an expression ${ }^{(4)}$, or simply the name of Djer repeated ${ }^{(5)}$.

(1) A. GaRdiner, Egyptian Grammar, London, 1950, p.481; R.O. FAULKNER, A Concise Dictionary of Middle Egyptian, Oxford, 1962, p.114; D. CINTRON, More on Decoding the Label of King Djer, p.1 in: www.academia.edu/227457, (Accessed 12/1/2016).

${ }^{(2)}$ M. BAUD \& M. ÉTIENNE, "Le vanneau et le couteau. À propos d'une scène de « sacrifice » sur deux étiquettes thinites”, Archéo-Nil 10 (2000), p. 58.

${ }^{(3)}$ FAULKNER, op.cit., p.272

(4) Ibid., p.271

(5) Cintron, loc.cit. 


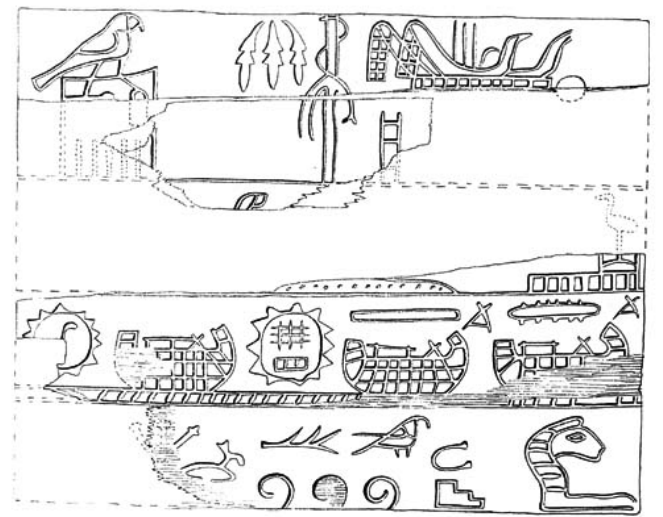

Fig. 6

Abydos label (BM 35518)

The label shows an official visit of Hor Aha to two of the most important shrines. It consisted of four horizontal registers:

a) The $1^{\text {st }}$ one, on the left, is the "serekh" as the personification of Horus Aha. Facing him, the sign of god Amiut (an archaic form of Osiris). Behind it, two sacred boats float.

b) The $2^{\text {nd }}$ record, here practically lost.

c) The $3^{\text {rd }}$ record, still confused interpretation, presents a group of ships that are sandwiched between two walled cities, Sais and Buto.

d) The $4^{\text {th }}$ record, is occupied by a text that appears to reveal the contents of the jar itself as: "300 steps of 'Fragrance of Horus' "(an oil $)^{(1)}$.

Decoding the related elements of the studied labels scene:

There are various suggestions that discussed little understood proto-hieroglyphs and not understood elements appeared in one of the

${ }^{(1)}$ WILKINSON, op.cit., pp. 317-320. 


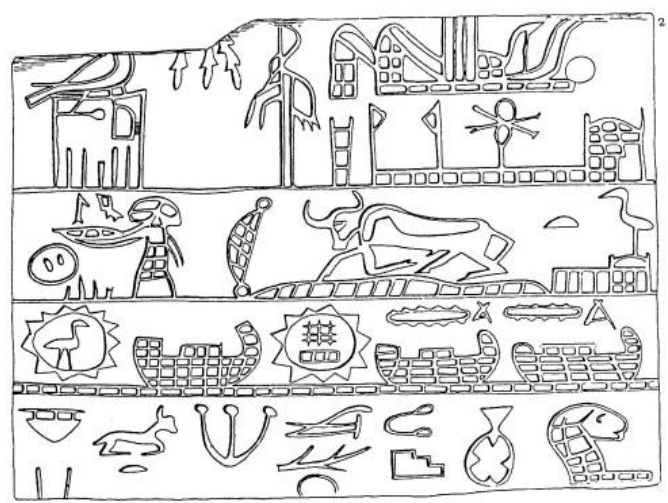

Fig. 5

Abydos label B19 (Hor-Aha)

(Philadelphia, University Museum E.9396)

There are traces of red pigment in the incised decoration. The scenes of this label divided into four registers. The most important depictions are the two upper rows. The detail of the top row shows an Egyptian temple with two flags and the standard of the goddess Neith $^{(1)}$.

In the $2{ }^{\text {nd }}$ row, a bird, probably the ibis of Thoth ${ }^{(2)}$, sits upon the roof of the temple of Lower Egypt, which has a high extension at its left side, probably around an inner yard. Most likely this holy house was made of the basic material - $\operatorname{reed}^{(3)}$.

\section{Fourth label:}

A fragmented ebony label of Hor Aha, with a reference to a shrine. Originally, it is from Abydos, now in the British Museum 35518, (Fig 6) ${ }^{(4)}$.

\footnotetext{
${ }^{(1)}$ LEGGE, op.cit., p. 21.

${ }^{(2)}$ PETRIE, op.cit., p.51.

(3) WeILl, op.cit., p.1; O. Vendel, "The Spirits of Nature, Religion of the Egyptians", in: blog.sina.com .cn/s/blog_5bo88co7o1ooiwae.html (accessed in Sept. 10, 2015).

(4) Petrie, op.cit., pl.10.3, pl. 3A.6; LegGe, op.cit., p. 24; Serrano, op.cit., p. 60 f.
} 


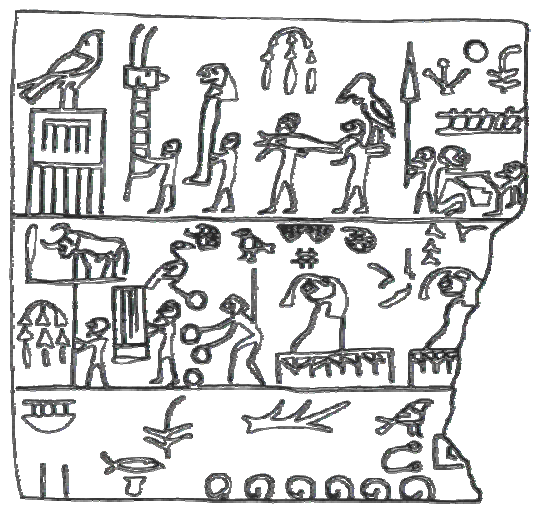

Fig. 4

A label from the reign of the Horus Djer (Cairo $J E$ 70114) $)^{(1)}$

It is divided into three rows:

1) The $1^{\text {st }}$ row shows a procession towards the serekh of Djer on the left and a ceremony on the right.

2) The $2^{\text {nd }}$ row illustrates a procession to the left followed by an activity and two seated figures.

3) The $3^{\text {rd }}$ row consists of seemingly random signs ${ }^{(2)}$.

\section{Third label:}

Large rectangular ebony label with the name of King Aha (Philadelphia, University Museum E. 9396)(3), (seen in fig. 5).

${ }^{(1)}$ WILKINSON, op.cit., p. 267 , fig. 2.

${ }^{(2)}$ EMERY, op.cit., p.35, fig. 8.

(3) PETrie, op.cit., pl.10.2, pl. 3A.5; G.F. LEGGE, "The tablets of Negadah and Abydos", PSBA 29 (1907), pp.18-24; V. VIKENTIEV, "Les monuments arehaïques. IV-V. - Deux rites du jubilé royal à l'époque protodynastique", BIE 32 (1951), p.202; VANDIER, op.cit., p. 837; D. O'CONNOR, "The Earliest Pharaohs and the University Museum. Old and New Excavations: 1900-1987", Expedition 29/1 (1987), p. 33, fig.11; HELCK, op.cit., S. 148; A.J. Serrano, Royal Festivals in the Late Predynastic Period and the First Dynasty, Oxford, 2002, p.57-60. 
1) The serekh [façade of the royal palace] of Aha on the left tof

2) A building as a prototype of the palace $\operatorname{sign}^{(1)}$.

3) Two hieroglyphic signs of sw-planet and papyrus $\$ \vec{V}$ are followed by a mysterious hieroglyphic sign 오올 group writing.

4) Separated hieroglyphic sign ms 1 th on the right top.

5) A seated man plunging a knife (?) into another seated man's chest while a standing man is holding a stick and watching them

6) A falcon on flag 昂.

7) An inscription seemingly symbol on stand 窟.

\section{Second label:}

An ivory label from the reign of King Djer $\left(95^{\times 85^{\times}} 4 \mathrm{~mm}\right)$, found by Emery at Mastaba of Hemaka no. 3035 at Saqqara (Cairo Museum, $J E$ $70114)^{(2)}$, (Fig. 4).

\footnotetext{
${ }^{(1)}$ K. SETHE, Beiträge zur ältesten Geschichte Ägyptens, Leipzig, 1905, S. 19.
}

${ }^{(2)}$ W.B. EMERY, The tomb of Hemaka. Excavations at Saqqara, Cairo, 1938, pp.35-39, fig. 8, pl. 17A, 18A, 59, fig. 21; S. Schott, Hieroglyphen, Wiesbaden, 1951, pl. 7; fig. 16; J. Vandier, Manuel d'archéologie egyptienne. I: Les époques de formation, Paris, 1952, p.845; V. Vikentiev, "Les monuments archaïques. VI. La tablette en ivoire d'un haut fonctionnaire du roi de la $I^{\text {re }}$ dynastie Wenewty-Ouénéphès", BIE 36/2, 1955, p.311; R. Weill, Recherches sur la I ${ }^{\text {re }}$ dynastie et les temps prépharaoniques, II, Le Caire, 1961, pp. 6, 61-3; W. Helck, Untersuchungen zur Thinitenzeit, Wiesbaden, 1987, S.153; M. OHSHIRO, "Decoding the Wooden Label of King Djer", GM 221 (2009), pp. 57, 6o, fig.1. 

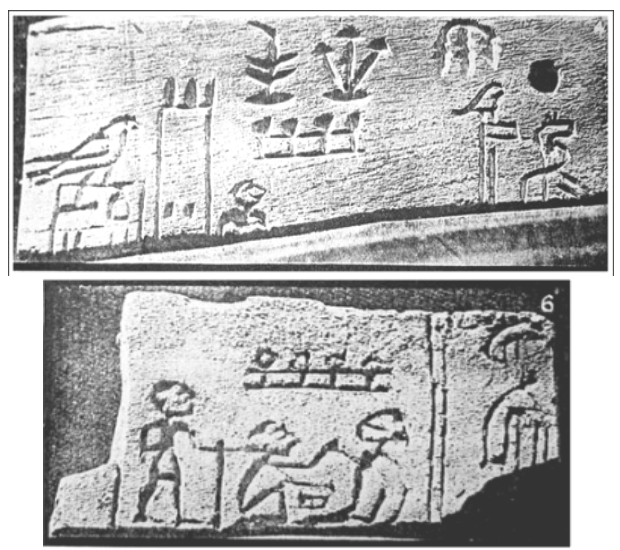

Fig. 2

Two fragmentary labels from the time of the Horus Aha (Cairo Mus. $J E$ 34907-8)(1)

If these two separated fragments are gathered together in one scene row, according to the integration in topic between the two pieces, they will illustrate the following elements (Fig. 3):

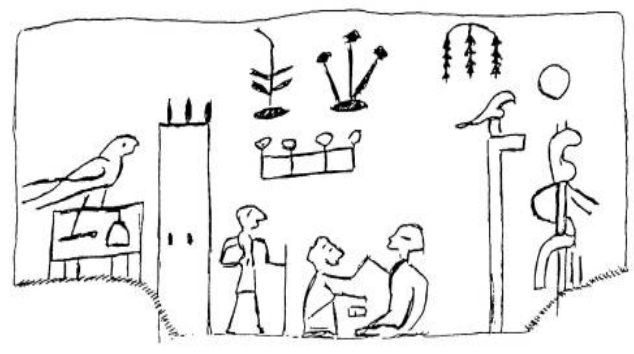

Fig. 3

A supposed scene of two fragmentary labels of the king Aha ${ }^{(2)}$

\footnotetext{
${ }^{(1)}$ WILKINSON, op.cit., p. 267, fig. 1.

${ }^{(2)}$ W.M.F. PetRIE, The Royal Tombs of the Earliest Dynasties, II: The Royal Tombs of the First Dynasty, EEF 21, London, 1901, pp. 20, 49, pl. 3.2,4.
} 


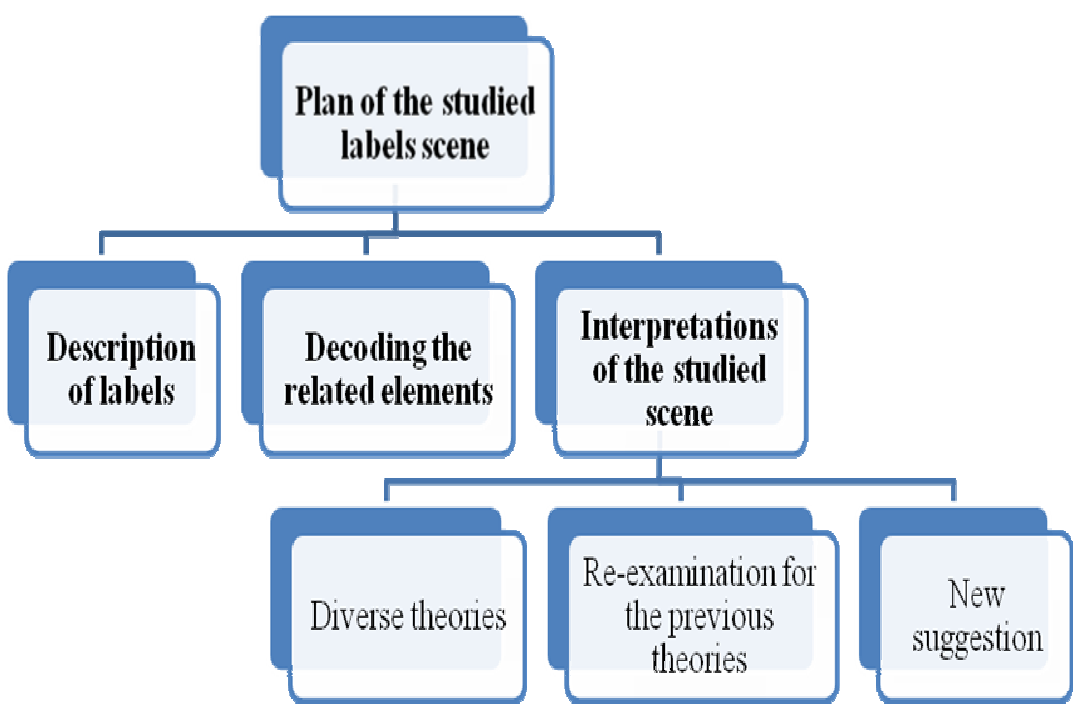

Fig. 1

Plan of the studied labels scene

\section{Description of labels:}

Primarily, the definition of "label" denotes to a small rectangular piece of wood, bone or ivory ${ }^{(1)}$. It inscribed with characters and attached to an object by means of piece string threaded through a hole in one corner of the label ${ }^{(2)}$. Now, a brief description of these labels:

\section{First label:}

Two broken ivory fragments of labels (Cairo Museum, $J E$ 34907-8), dated to the time of Aha (Fig. 2), found in Abydos (Cemetery B) ${ }^{(3)}$.

(1) P.E. NewBERRY, "The Wooden and Ivory Labels of the First Dynasty," PSBA 34 (1912), p.279.

${ }^{(2)}$ T.A.H. WiLKINSON, Early Dynastic Egypt, London - New York, 2001, p. 371.

${ }^{(3)}$ Cf. B.J. Kemp, "Abydos and the Royal Tombs of the First Dynasty." JEA $5^{2}$ (1966), pp.13-22. 


\section{A NEW INTERPRETATION OF AN AMBIGUOUS SCENE ON THE FIRST DYNASTY LABELS}

MOHAMED MAHMOUD KACEM

\section{Introduction:}

There are some labels of ivory, dated to the beginning of $1^{\text {st }}$ Dynasty, depict some ambiguous figures and not understood events owing to absence of the illustrative inscriptions. The most important scene shows a seated man plunging a knife into another seated man's chest. The scholars studied it and firmly believed that scenes denote to the existence of human sacrifice to the gods as offerings, or to the kings to serve them in the Netherworld, but without giving attention to many related and artistic elements of those labels scenes. Therefore, this paper tries to collect many relevant facts and give numerous documentary proofs; to present a complete and new interpretation about these depictions according to the following plan (Fig. 1). 

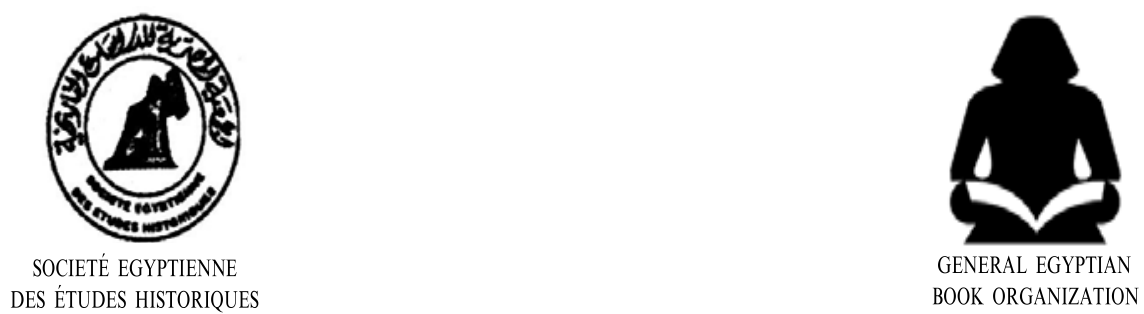

SOCIETÉ EGYPTIENNE

DES ÉTUDES HISTORIQUES

\section{REVUE EGYPTIENNE DES ÉTUDES HISTORIQUES}

VOL 52

LE CAIRE

2018 

REVUE EGYPTIENNE

DES ÉTUDES HISTORIQUES 